L. ZHANG, N. SHANG, S. GAO*, J. WANG, T. MENG, C. DU, T. SHEN, J. HUANG, Q. WU, H. WANG, Y. QIAO*, C. WANG*, Y. GAO*, Z. WANG (HEBEI AGRICULTURAL UNIVERSITY AND HEBEI UNIVERSITY, BAODING, AND YANSHAN UNIVERSITY, QINHUANGDAO,

P. R. OF CHINA)

Atomically Dispersed Co Catalyst for Efficient Hydrodeoxygenation of Lignin-Derived Species and Hydrogenation of Nitroaromatics

ACS Catal. 2020, 10, 8672-8682, DOI: 10.1021/acscatal.0c00239.

\section{A Single-Atom Cobalt Catalyst Supported on SBA-15 for Hydrodeoxygenation and Hydrogenation}
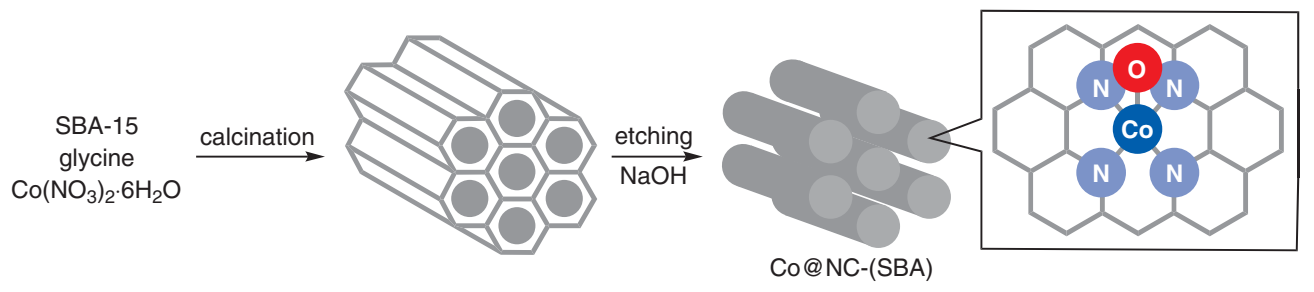

Category

Polymer-Supported

Synthesis

\section{Key words}

cobalt catalysis

single-atom catalyst

hydrodeoxygenation

hydrogenation

lignin-derived

species

nitrobenzenes

Selected results:<smiles>COc1cccc(C)c1O</smiles>

$99 \%$ conversion $99 \%$ selectivity<smiles>COc1cc(C(O)O)ccc1O</smiles>

$100 \%$ conversion $99 \%$ selectivity<smiles>CCc1ccc(O)c(C(C)C)c1</smiles>

99\% conversion $99 \%$ selectivity

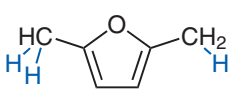

99\% conversion $83 \%$ selectivity

Hydrogenation of nitrobenzenes:

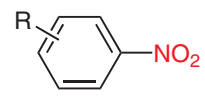

$$
\underset{\mathrm{H} \text { (10 bar), EtOH, } 90^{\circ} \mathrm{C}, 1-2 \mathrm{~h}}{\stackrel{\mathrm{C}}{\longrightarrow}}
$$

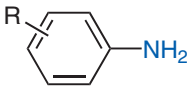

Selected results:
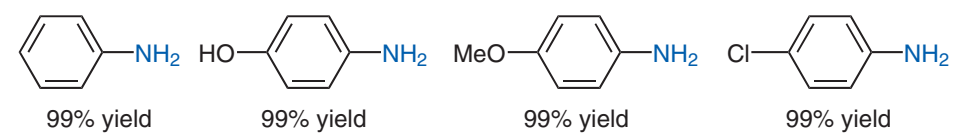

$99 \%$ yield

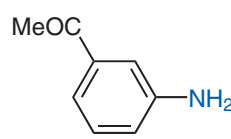

$99 \%$ yield
Significance: A single-atom cobalt catalyst supported on porous nitrogen-doped carbon [Co@NC(SBA)], prepared according to Equation 1, catalyzed the hydrodeoxygenation of lignin-derived compounds (eq. 2) and the hydrogenation of nitrobenzenes (eq. 3) to give the corresponding products with up to $99 \%$ selectivity and $99 \%$ yield.
Comment: In the hydrodeoxygenation of vanillin, the catalytic activity of Co@NC-(SBA) was clearly superior to that of Co catalysts supported on various silicas (MCM-41, FDU-12) and to that of various metals (Fe, Ni, $\mathrm{Cu}$ ) supported on SBA-15. In the hydrogenation of $p$-nitrochlorobenzene, the catalyst was reused nine times without loss of its catalytic activity. 